\title{
Glanzmann thrombasthenia - presenting as prolonged severe bleeding following minor trauma
}

\author{
R N Morawakkorala ${ }^{1}$, A M R D Senarathna ${ }^{1}$, AC D de Alwis ${ }^{2}$, V Rathnamalala ${ }^{3}$
}

Sri Lanka Journal of Child Health, 2006; 35: 36-7

(Key words: Glanzmann thrombasthenia)

\section{Introduction}

Glanzmann thrombasthenia (GT) is an inherited haemorrhagic disorder characterized by a severe reduction in, or absence of, platelet aggregation in response to multiple agonists due to qualitative or quantitative abnormalities of platelet glycoprotein (GP) $11 \mathrm{~b}$ and/or $111 \mathrm{a}^{1,2}$. Glanzmann, a Swiss paediatrician, described a group of patients with haemorrhagic symptoms especially of nasopharynx in $1918^{1}$.

\section{Case report}

A five year old boy from Ratnapura presented with continuous bleeding for more than 36 hours from upper lip following trivial trauma after a fall in the pre-school. On admission the child was in hypovolaemic shock and severely pale with a haemoglobin $(\mathrm{Hb})$ of $5 \mathrm{~g} / \mathrm{dl}$. Initial resuscitation was done with normal saline $20 \mathrm{ml} / \mathrm{kg}$, fresh frozen plasma $15 \mathrm{ml} / \mathrm{kg}$ and fresh blood $15 \mathrm{ml} / \mathrm{kg}$. The bleeding was arrested with tranexamic acid 500mg and local pressure.

He was a product of a non-consanguineous marriage, delivered at term. A moderate sized cephalhematoma and few ecchymotic patches were noted at birth. Two episodes of haematuria and one episode of epistaxis were noted at two and three years of age.

Investigations revealed normal platelet count $(351 \mathrm{x}$ $\left.10^{9} / \mathrm{L}\right)$, prolonged bleeding time ( $>10$ seconds), normal prothrombin time (both test \& control 12 seconds) and normal activated partial thromboplastin time (test 22 seconds \& control 26 seconds). Blood picture showed normochromic normocytic red cells and normal white blood cells.

${ }_{1}^{1}$ Registrar in paediatrics, ${ }^{2}$ Consultant Paediatrician,
${ }^{3}$ Consultant Haematalogist, General Hospital
Ratnapura.

(Received on 4 October 2005. Accepted 20

November 2005).
Although the number and morphology of platelets were normal clumping was absent. Electron microscopy identified normal amount of granules in platelets. Platelet function tests showed absent aggregation with ADP $10 \mu \mathrm{M}$, collagen $2 \mu \mathrm{g}$, arachidonic acid $2 \mu \mathrm{M}$ and normal response to ristocetin $1.2 \mathrm{mg} / \mathrm{ml}$.

\section{Discussion}

Glanzmann thrombasthenia is a rare disorder with an autosomal recessive inheritance and worldwide distribution ${ }^{1}$. The platelet GPIIb/IIIa receptor is required for platelet aggregation induced by all the agonists thought to operate in vivo (ADP, epinephrine, thrombin, collagen, thromboxane $\mathrm{A} 2)^{1,2}$. Consequently, abnormalities in the receptor result in failure of platelet plug formation at sites of vascular injury, leading to excessive bleeding and bruising ${ }^{1,2}$. The GPIIb/IIIa receptor is also responsible for the uptake of fibrinogen from plasma into platelet alpha granules. Patients with GT have markedly reduced levels of platelet fibrinogen ${ }^{1}$. Clot retraction requires platelets with intact GPIIb/IIIa receptors, presumably to make contact with fibrin, and patients with GT usually have abnormal clot retraction ${ }^{1}$. Defects in either GPIIb or IIIa result in the same functional defect because both subunits are required for receptor function ${ }^{1}$.

Clinically patients can present with purpura immediately after birth but often not as dramatic as in our patient. Petechiae of the face and subconjunctival hemorrhage associated with crying may be the symptoms in neonates. Epistaxis is a common symptom and can be life threatening. Gingival bleeding can be a chronic source of blood loss, especially if dental hygiene is poor ${ }^{1,3}$. Spontaneous haemarthrosis is very rare; this distinguishes GT from haemophilia, von Willebrand disease and related disorders $^{1}$. The platelet abnormalities in GT undoubtedly increase the risk of bleeding; when there is minor trauma it may be fatal unless prophylactic platelet transfusions are administered ${ }^{1}$. 
Patients have normal platelet counts and morphology, prolonged bleeding time, decreased or absent clot retraction, and abnormal aggregation responses to all agonists but normal or near normal aggregation with ristocetin ${ }^{1}$. Platelet GPIIb/IIIa can now be quantitated by monoclonal antibody binding and immunoblotting ${ }^{1}$.

When a patient presents with significant bleeding with minor trauma and investigations show a prolonged bleeding time, normal platelet count and morphology, normal PT and APTT Glanzmann thrombasthenia should be considered as a possibility ${ }^{4}$.

Therapy involves both preventive measures and treatment of specific bleeding episodes ${ }^{1}$. Antiplatelet agents should be avoided. Hepatitis B vaccine should be administered early in life. Dental hygiene is important in minimizing gingival haemorrhage.

Antifibrinolytic agents may be useful in patients with gingival bleeding or who are undergoing tooth extractions. Transfusion of platelets is the mainstay of therapy for serious bleeding in GT and as prophylaxis prior to surgery or other major haemostatic stresses ${ }^{1}$.

\section{Acknowledgements}

We thank Dr (Mrs) N Ekanayake, Consultant Pathologist, MRI for performing the electron microscopic examination of the platelets and $\mathrm{Mr}$. P Wickramasinghe, MLT, MRI for doing the platelet function tests.

\section{References}

1. Beutler E, Lichtman MA, Coller BS, Kipps TJ, Seligsohan U. editors, Williams Hematology $6^{\text {th }}$ ed. USA; Megrans-Hill Medical Publishing Division, 2001:1551-60.

2. Hoffbrand AV, Pettit JE. Editors, Essential Haematology, $3^{\text {rd }}$ ed. USA; Blackwell Science Ltd, 1993.

3. George JN, Caen JP, Nurden AT. Glanzmann thrombasthenia: the spectrum of clinical disease. Blood 1990; 75:1383.

4. Thomas AE. The bleeding child; is it NAI? Archives of Diseases in Childhood 2004; 89:1163-7. 